year. This figure, however, represents an increase of only 4 per cent as compared with a 12 per cent increase in Great Britain as a whole, and a 38 per cent increase in unemployment on Merseyside as compared with 16 per cent in Great Britain. Moreover, although the high level of unemployment on Merseyside has not altered very much in the last twelve months, the August figures indicating an increase of less than 2 per cent, the cost of its relief has increased. Unemployment insurance payments in August 1938 were nearly a fifth greater than in August 1937, while unemployment allowances were more than 5 per cent less. Although this position is due partly to the increases in benefit made this year by the Beveridge Committee and the fall in the cost of the means test, to long-standing cases getting work, to final 'cuts' under the 'Standstill Act', and to the revised system of relieving casual labour, the fact that the means test is costing less and benefit more, while unemployment remains much the same, is unexpected.

The cost of outdoor relief decreased between June 1937 and June 1938, but able-bodied unemployed still cost the ratepayers of Merseyside $£ 38,000$ a month, $£ 6,200$ of which goes to insured workers. Mr. Caradog Jones refers once more to an unfortunate gap in the social services. If an insured person falls sick, he ceases to qualify either for unemployment benefit or for unemployment allowance ; he is entitled to sickness benefit, but this takes no account of dependants, and he is therefore frequently driven to apply for poor relief. This is an additional trial to the mind when the body is least able to stand it. Mr. Jones also refers to the absence of anything but poor relief for non-manual workers, such as ships' officers, salesmen and clerical workers who when in work were earning more than $£ 250$ a year.

A section on education indicates the difficulties which many teachers in elementary schools in the area have to face as well as the points at which reorganization on the lines of the policy laid down in the Hadow report is most backward. The housing situation is summarized in a further section and particulars of rents and rates are analysed in a final table. The whole handbook, brief as it is, affords an admirable example of the presentation of facts in a manner designed to stimulate appropriate action.

\title{
The Highgate Literary and Scientific Institution Centenary Celebration
}

$\mathrm{O}^{\mathrm{N}}$ $\mathrm{NE}$ of the marked features of the intellectual life of the early years of the nineteenth century was the founding of philosophical, literary or scientific institutions, or societies where lectures could be delivered, discussions held and where libraries could be formed and housed. Many of these institutions, especially those in small towns, have disappeared, or parts of their activities have been absorbed either in the local free library, or in the neighbouring technical college.

Some of the societies have survived and are doing most useful work : amongst these may be mentioned the Cambridge Philosophical Society, the Royal Glasgow Philosophical Society, the Manchester Literary and Philosophical Society, the Leeds Philosophical Society, and the Highgate Literary and Scientific Institution, which has just celebrated its centenary.

Exactly one hundred years ago, on January 16, 1839, a meeting was held at the Gate House Tavern, Highgate, to consider the formation of a society, or, in the quaint words of the invitation card, "for the purpose of forming an Institution designed to excite and cultivate an intelligent interest in the objects of literature and science". The first president was Mr. Harry Chester, who served in that capacity for eighteen years. The Society was evidently welcomed by the inhabitants of Highgate, because at the end of a month the president in his first presidential address was able to state that 110 members and associates had been elected, and that four hundred volumes had been placed in the library, of which three hundred were donations.

The founders were determined that the Institution should be democratic, as is shown by the opening remarks of the president: "This is a voluntary Association of many for the benefit of all and open to all; it is no exclusive Association, to which admission depends on the likes and dislikes of indiv. iduals. Here all classes may meet without annoyance to any : and therefore with advantage to all."

In May 1840, the premises the Institution still occupies were rented from the trustees of the estate of Sir John Hawkins, who was an executor, and also a biographer, of Dr. Samuel Johnson. In 1932 it was found possible to purchase the freehold of the property, and in 1936 that of the immediately adjoining property, thus giving the opportunity for further future extensions.

The annual reports of the committee of management of the Institution give a brief story of its activities. In the seventh report (unfortunately, the first six reports are missing) a list of the periodicals in the reading room for the year 1846 is given. It is interesting to note that Blackwood's, Chambers's Journal, the Edinburgh Review and the Quarterly Review were mentioned; the remaining periodicals are no longer in existence.

The formation and maintenance of the library has always been regarded as one of the chief duties of the committee of management. The library now consists of more than 11,000 volumes, and includes $\mathbf{a}$ con. siderable number of books of reference. It must be confessed that the scientific side of the library has been allowed to lapse more than it should have done.

The giving of lectures by well-known experts and authorities has always formed an important activity of the Institution. It has been estimated that some 1,700 lectures on the greatest variety of subjects have been given during the past century. Looking back through the annual reports, the development of many of the sciences can be traced by the names of the lecturers and their subjects. "The Proposed Atlantic 
Telegraph" (1857), "The Electric Light" (1881), "Polarized Light" (1881) by Mr. William Spottiswoode, then president of the Royal Society, "The Habits of Ants" (1884) by Sir John Lubbock, "Fireworks. Their Chemistry and Mechanics" (1886) by C. V. Boys, "An Evening with the Telescope" (1896) by Sir Robert Ball; and then down to the present time "Large Telescopes" (1937) by the Astronomer Royal, and "Links with the Past in the Plant World" (1938) by Sir Albert Seward. That the artistic and literary side of the Institution has not been neglected may be gathered from the fact that Prof. Henry Morley and Prof. S. R. Gardiner delivered courses of lectures on "Chaucer and the English Writers" and "On the History of England" respectively. Amongst modern writers who have spoken at the Institution may be mentioned Mr. John Drinkwater, Mr. J. B. Priestley and Sir William Rothenstein.

To commemorate the centenary of the Institution, an appeal has been launched to enable some alterations and additions to be made to the old buildings. At the centenary dinner, held at the Criterion Restaurant on January 16, the president (Mr. R. S. Whipple), replying to the toast of "The Institution", which had been proposed by Sir Ian Fraser, mentioned that the sum of $£ 1,327$ had been promised-a good beginning, although much more is required. Sir Robert Waley Cohen proposed the health of the visitors, to which the Mayor of St. Pancras and Prof. Allan Ferguson replied. The latter dwelt on the usefulness of institutions such as that of Highgate as centres of intellectual activity.

\section{Additional Evidence of Early Man in America} WURTHER particulars of the Borax Lake site,
Lake County, California, on which relics of the
Folsom and the earlier Mohave Lake cultures have
been found, are made available in a preliminary
report to the Carnegie Institution, Washington, by
Mr. M. R. Harrington of the South Western Museum,
Los Angeles, who was engaged in exploratory
investigation there from July 1937 until June
1938.

The bed of Borax Lake is now dry, except for a little saline water at the north-west end. It is surrounded by hills, $300-400 \mathrm{ft}$. high ; but at the southeast it is separated from the Clear Lake basin by a ridge $100 \mathrm{ft}$. high only. A number of small canyons drain into the lake bed. Their alluvial fans are insignificant, with one exception, on which is evidence of human occupation over a considerable period going back to a time even before the formation of the fan began.

On the surface, Folsom and Mohave points occurred with other elements of the two cultures, as well as a certain archaic type of stemmed projectile point, now named 'Borax Lake' from its relative abundance. With these were a few modern chipped obsidian points. Excavation revealed abundant artefacts at a depth of five and a half feet in dark-coloured soil, and occasional finds in the underlying yellow gravels, sands and clays to a depth of eight feet. No true Folsom or Mohave points were found below the surface, but 'Silver Lake' points of the Mohave complex, Borax Lake points and a 'willow-leaf' type occurred. A keeled type was abundant in the lower part of the deposit with large scrapers and combined chopperscrapers. Smaller scrapers appeared practically throughout. Metatés, hammer-stones and pestles were found, but no shell or bone implements.

It is suggested that occupation, possibly seasonal, began with the pluvial which followed the Pleistocene ice age, and was abandoned at its close, when desiccation set in.

At the same time exploration and partial excavation of caves in south central Oregon, carried out from 1934 onward by Dr. L. S. Cressman, professor of anthropology in the University of Oregon, would now appear likely to have an important bearing on the date of man's appearance on the American continent. These caves, situated in what is now an extension of the Great Basin of the United States, were produced by the wave action of glacial lakes formed in dammed valleys during the Pleistocene period. On the recession of the ice and the onsetting of gradual desiccation the lakes disappeared, leaving the caves high and dry. One cave explored, for example, is two hundred feet above the valley floor. The caves were then occupied by man for some considerable time. Dr. Cressman has excavated occupational debris to a depth of nine feet or more.

In a preliminary report, also addressed to the Carnegie Institution, on excavations in 1937 at Catlow Valley and in three other localities, which were supported financially by the Institution, it is stated that numerous artefacts were discovered. These included basketry, sandals and black, undecorated potsherds. Faunal bones indicate a change of diet from mainly waterfowl and small rodents in the lower levels to large mammals, deer, bison and mountain sheep, in the upper.

Of two finds of human skeletal remains, one, consisting of a skull and other parts, was embedded about six inches deep in gravels at the north end of the cave and almost under the rear wall. This was about seven feet below the surface of the cave deposits. Absence of clear stratification in the cave invests this discovery with some ambiguity; but Dr. Cressman inclines to the view that the body was deposited in the gravels by wave action, when it was partially decomposed, but still covered with flesh, thus accounting for the unscratched condition of the bones and the circumstances of deposit. This could have happened only when the lake had begun to fall, but storm waters still invaded the cave, that is, not more than 15,000 years ago. It is, therefore, in Dr. Cressman's view, "entirely likely that we have here a representative of early man in the New World".

In two cave sites, one at Paisley and one at Fort Rock, a layer of pumice overlay the earliest evidence of human occupation. The earlier of these, that at Paisley, is assigned to an age of about 10,000 years.

In view of the abundance of fresh water and game in this early period, Dr. Cressman concludes not only that numerous traces of early man will be found in this area, but also that it may have served as the line of advance to Central America of the Asiatic immigrants. 